\title{
Perubahan Jalur Pelayaran Terhadap Peta Perekonomian Asia Tenggara Dampak Pembangunan Terusan Kra Thailand
}

\author{
Aninditya Gita Kireina Persada*, Lazarus Tri Setyawanta \\ Magister Ilmu Hukum, Fakultas Hukum, Universitas Diponegoro \\ Jl. Imam Bonjol 1, Pleburan, Semarang, Jawa Tengah 50241 Indonesia \\ ${ }^{*}$ Corresponding autor, e-mail: anindityagkp@yahoo.com
}

\begin{abstract}
ABSTRAK: Terusan Kra merupakan kanal yang telah direncanakan pembangunannya oleh Thailand sejak abad ke-17. Dengan dibangunnya terusan Kra yang dimungkinkan berhasil memberi efisiensi terhadap penyingkatan waktu pelayaran di daerah Asia Pasifik tentu akan memberi dampak kerugian yang signifikan pada terusan Malaka yang telah terlebih dahulu dibuat. Dampak pembangunan tersebut akan mempengaruhi perubahan jalur pelayaran serta merubah peta perekonomian Asia Tenggara secara makro. Tujuan dari tulisan ini ada untuk mengetahui dampak dan perubahan signifikan terhadap pembangunan terusan Kra di masa depan. Metode yang digunakan merupakan pendekatan yuridis normatif yang menggunakan data sekunder melalui penelitian kepustakaan dan studi dokumen. Adanya terusan Kra akan merubah neraca ekspor dan impor secara signifikan serta akan memberikan perubahan besar ke beberapa negara-negara di Asia Pasifik. Hingga saat ini mulai banyak negara-negara di Asia Tenggara yang mulai merencanakan dan membangun kawasan pantainya agar dapat bersaing saat nantinya Terusan Kra dibuka.
\end{abstract}

Kata Kunci: Terusan Kra; Asia Tenggara; Dampak; Perubahan Jalur Pelayaran

\section{The Changing of Shipping Lanes Towards Map of Southeast Asia Economy The Impact of Thailand's Canal Kra}

ABSTRACT: The Kra Canal is a canal that Thailand has planned to build since the 17th century. With the construction of the Kra canal, which is possible to provide efficiency in reducing shipping time in the Asia Pacific region, it will certainly have a significant impact on the Malacca canal that was previously built. This development impact will affect changes in shipping lanes and change the economic map of Southeast Asia at a macro level. The purpose of this paper is to determine the impact and significant changes to the development of the Kra canal in the future. The method used is a normative juridical approach that uses secondary data through library research and document study. The existence of the Kra canal will change the export and import balance significantly and will provide big changes for several countries in Asia Pacific. Until now, many countries in Southeast Asia have started planning and building their coastal areas so that they can compete when the Kra Canal opens.

Keywords: Kra Canal; Southeast Asia; Impact; Changes in Shipping Lane

\section{PENDAHULUAN}

Terusan Kapal atau terusan merupakan kanal yang digunakan sebagai sarana guna mempercepat pelayaran kapal yang merupakan saluran air buatan sehingga dapat digunakan untuk mengarahkan dan mengalirkan air atau digunakan untuk mengangkut barang dan orang. Menurut fungsinya, kanal berperan dalam mempersingkat lama waktu atau jarak tempuh pelayaran agar lebih efektif. Dalam Perairan Kepulauan, Terusan merupakan bagian dari perairan pedalaman yang berada di dalam sisi garis pangkal normal. Secara rinci, klasifikasi terusan tidak disebutkan dalam United Nations Convention on the Law of the Sea (UNCLOS). Terusan Suez yang dibangun pada 1869 merupakan terusan yang menghubungkan Laut Tengah ke Laut Merah. Terusan Suez merupakan kanal yang sukses membuat seluruh dunia menyadari akan pentingnya menyingkat 
waktu pelayaran dengan terusan. Sejak saat itu, negara-negara semakin gencar membangun terusan kapal.

Terusan Kra yang akan membelah daratan Thailand sudah sejak tahun 1677 direncanakan oleh Raja Narai ketika arsitek Perancis, De Lamar, memiliki gagasan membuat terusan yang menghubungkan Songkhla dengan Marid. (Harahap, 2019) Setelah adanya perencanaan tersebut, terjadi beberapa masalah yang timbul mulai dari ekonomi, politik hingga investasi perencanaan yang membuat ditundanya proyek tersebut dan berhenti (Su, 2015; Sulong, 2012)

Hal tersebut kemudian direalisasikan oleh Thailand untuk membangun jalan Sutra dengan China yang berbentuk joint venture dengan ditandatanganinya MoU 'the China - Thailand Kra Infrastructure Investment and Development' dengan Asia Union Group. Thailand dan China yang gencar akan meningkatkan perekonomiannya dengan memperpendek lintasan kapal dari Laut Andaman ke Laut Cina Selatan dan sebaliknya tanpa harus melintasi semenanjung Malaka. Terusan Kra digadang-gadang akan menjadi jalur alternatif yang akan mempengaruhi dinamika geopolitik Asia Tenggara (Peng Er, 2018).

Terusan Kra sendiri akan berasa di wilayah selatan Thailand yang berdekatan dengan Malaysia. Terusan tersebut diperkirakan akan membentang dari provinsi Songkhla ke provinsi Satun dengan memotong jalur darat untuk dijadikan perairan, seperti layaknya Terusan Suez dan Terusan Panama. (Billington, 2016) Dengan panjang 102 kilometer, Terusan Kra nantinya akan berhasil memotong lama perjalanan sebanyak 72 jam atau 1200 kilometer dengan tidak dilewatinya Selat Malaka. Selat Malaka merupakan jalur transportasi laut internasional terpenting karena menghubungkan Samudera Hindia dengan Samudera Pasifik melalui Laut China Selatan dan rute laut terpendek antara kawasan Timur Tengah. Selat Malaka merupakan choke point minyak terbesar kedua di dunia setelah Selat Hormuz. (Rahman, et al., 2016). Jalur yang memiliki lebar $400 \mathrm{~m}$ dan kedalaman 25 m memungkinkan lewatnya kapal kargo besar hingga kapal induk supertanker terbesar di dunia saat ini (Maierbrugger, 2015; Rahman, et al., 2016)

Pembangunan Terusan Kra telah menjadi perhatian dunia sejak tahun 1983, saat Fusion Energy Foundation (FIF) membantu Kementerian Transportasi Thailand untuk melakukan studi kelayakan dengan fokus utama melihat keuntungannya bagi ekonomi Thailand (Tanapura, 1984). Mitsubishi Research Institute Jepang juga menginisiasi penggunaan Peaceful Nuclear Explosives (PNE) untuk menghancurkan bebatuan pegunungan sehingga dapat membuka perairan (Billington, 2016).

Dengan dibangunnya Terusan Kra yang dimungkinkan berhasil memberi efisiensi terhadap penyingkatan waktu pelayaran di daerah Asia Pasifik tentu akan memberi dampak kerugian yang signifikan pada Terusan Malaka yang telah terlebih dahulu dibuat. Sehubungan dengan adanya rencana tersebut, maka penelitian ini bertujuan untuk mengetahui dampak dan perubahan signifikan terhadap peta perekonomian negara-negara Asia Tenggara dengan adanya pembangunan terusan Kra di masa depan.

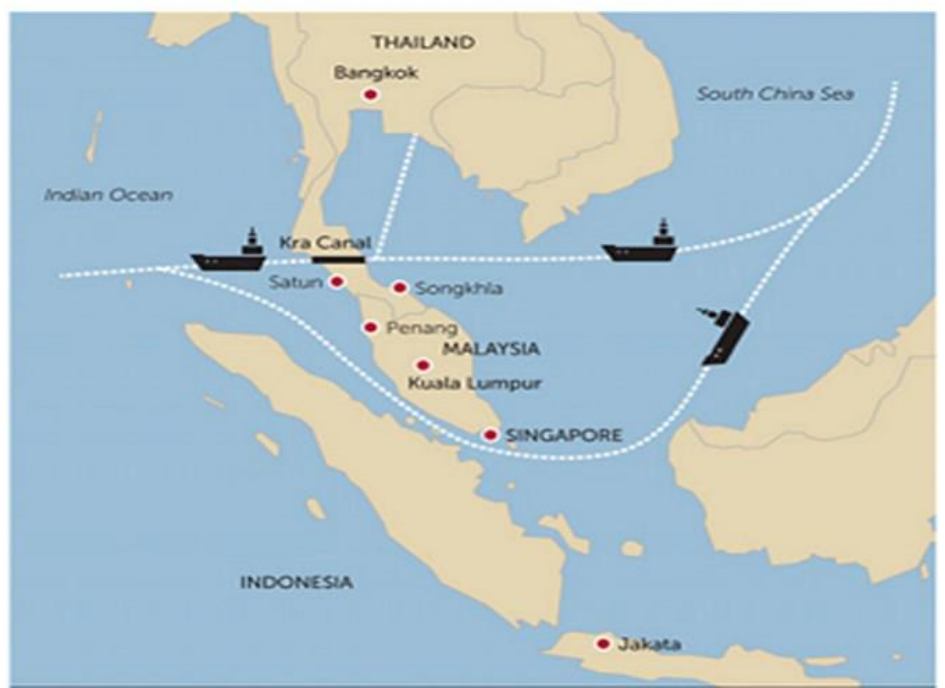

Gambar 1. Peta Rencana Jalur Terusan Kra di Thailand (Sumber: National Planning Agency) 


\section{MATERI DAN METODE}

Penelitian ini menggunakan metode pendekatan dan analisis data yuridis metode normatif (Tanapura, 1984). Teknik pengumpulan data yang digunakan merupakan penelitian kepustakaan dan studi dokumen. Bahan-bahan yang dikumpulkan sebanyak mungkin merupakan data yang mencakup rumusan masalah dan yang berhubungan dengan judul penelitian ini. Penyajian analisis kualitatif menyajikan pemahaman atas kebenaran yang menjadi latar belakang rumusan masalah serta akan lakukan penyaringan data yang sesuai untuk kemudian dapat dipaparkan dalam pembahasan untuk menjawab permasalahan, yaitu dengan memaparkan perkembangan pembangunan terusan Kra hingga perubahan jalur pelayaran apabila Terusan Kra selesai dibangun. Melalui studi literatur, studi dokumenter, dan penelitian lapangan yang terkait dengan substansi utama dari penelitian ini. Setelah data dikumpulkan, proses selanjutnya adalah untuk mengidentifikasi, untuk mengklarifikasi, dan menganalisis secara sistematis. Akhirnya, semua hasil penelitian disajikan dalam laporan akhir yang disusun.

\section{HASIL DAN PEMBAHASAN}

Dilihat secara geopolitik, Terusan Kra dapat dikatakan salah satu upaya China dalam menyelesaikan rencana Jalur Sutera Maritim yang diprediksi akan meningkatkan perekonomian China. Terbukti dengan usaha China yang menyediakan pinjaman hingga bantuan teknologi pada Pemerintah Thailand untuk mendukung pembangunan Terusan Kra. Proyek tersebut merupakan cara bagi China untuk menyelesaikan sejarah gemilang perekonomiannya. (Malaka, 2017; Lau \& Lee, 2016) The Silk Road Economic Belt yang dicanangkan oleh China nantinya akan menghubungkan China, Asia Tengah, Rusia dan Eropa. Jalur tersebut jika dijabarkan akan menghubungkan China dengan Asia Tenggara, Asia Selatan dengan Samudera Hindia dan yang terakhir menghubungkan ke Eropa melalui Laut Cina Selatan ke Pasifik Selatan (Rahmadani et al., 2019).

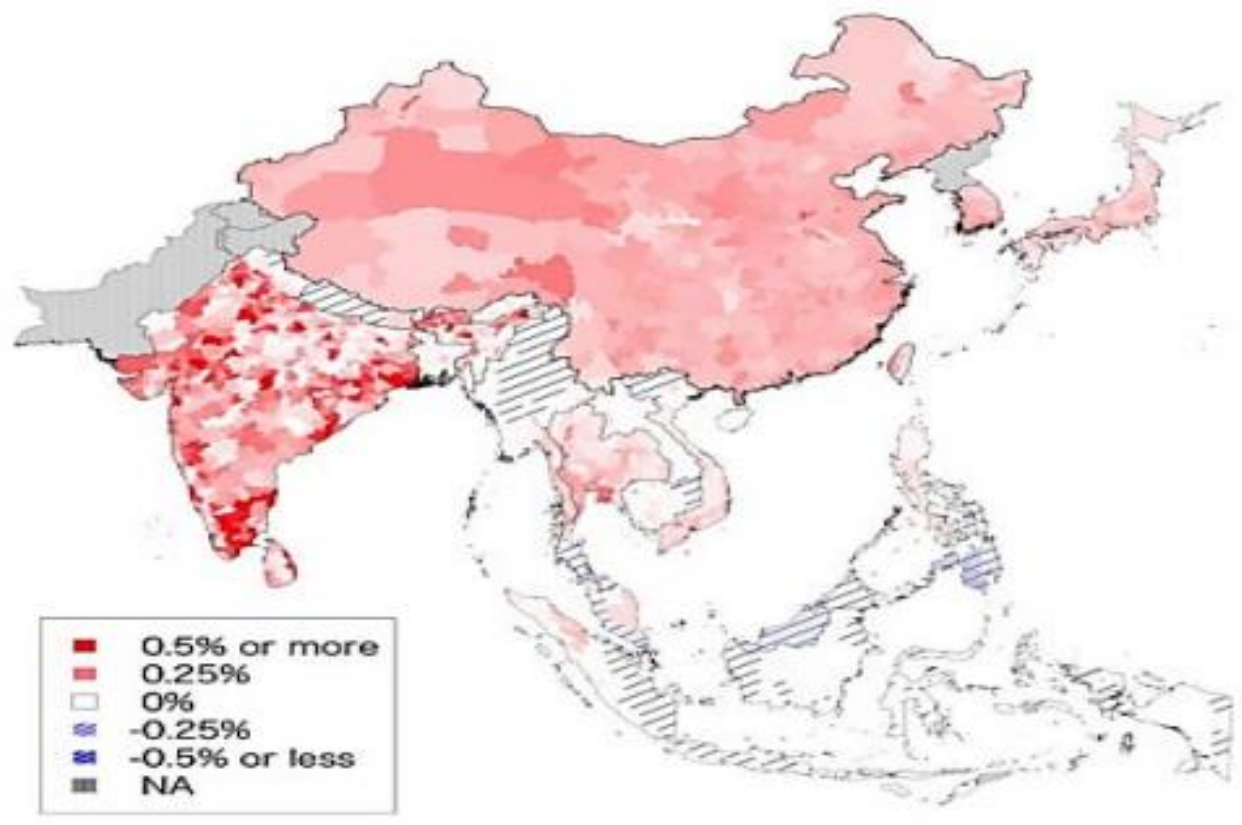

Gambar 2. Dampak Ekonomi dari Terusan Kra menurut Skenario 1 Pada Tahun 2030 (Sumber: Chen \& Kumagai, 2016)

Terusan Kra yang nantinya akan mengesampingkan Selat Malaka membawa dampak besar bagi perekonomian negara-negara yang menggantungkan perekonomian pada Selat Malaka. Pada 
tahun 2016, Institute of Developing Economies, Japan External Trade Organization (IDE-JETRO) mengeluarkan sebuah artikel yang memperkirakan dampak ekonomi bagi negara-negara sekitar (Chen \& Kumagai, 2016). Selain itu, organisasi tersebut juga menyebutkan bahwa pembangunan proyek akan menimbulkan beberapa scenario yang berpotensi terjadi, antara lain (Lau \& Lee, 2015): Pada Skenario 1 yang dibuat IDE-JETRO, Terusan Kra dan Selat Malaka hidup bersamaan. Pembangunan terusan Kra diperkirakan selesai pada tahun 2025. Pada saat itu, Terusan Kra dan Selat Malaka tetap beroperasi dengan memperhitungkan asa dan tujuan akhir pelayaran. Sehingga akan terpilih rute yang paling pendek dari salah satu perairan tersebut; Sedangkan dalam Skenario 2, Terusan Kra hidup dengan penutupan Selat Malaka dan akan digantikan dengan feeder dari Kanal Kra ke Singapura. Itu berarti Singapura akan turut campur dalam pengembangan Terusan Kra di kemudian hari.

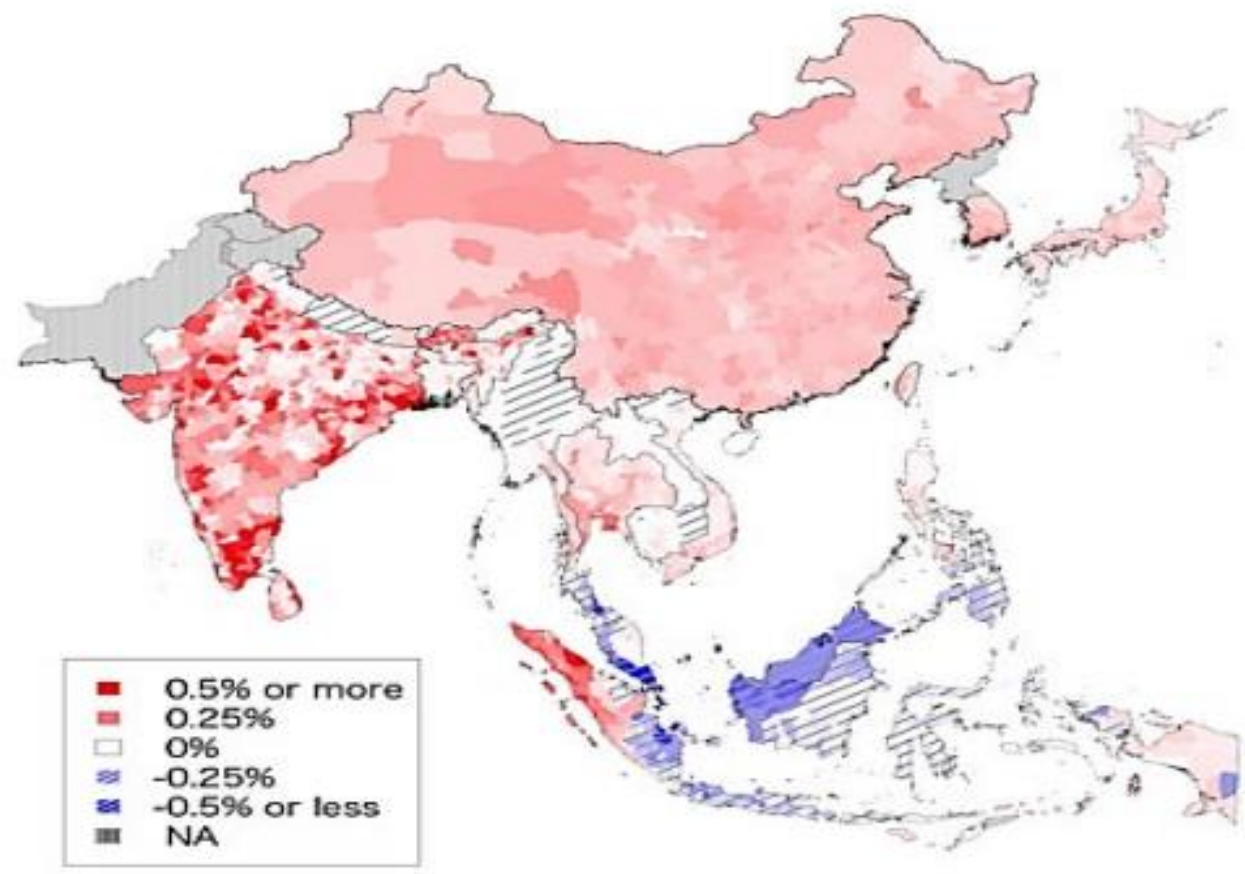

Gambar 3. Dampak Ekonomi dari Terusan Kra menurut Skenario 2 pada Tahun 2030 (Sumber: Chen \& Kumagai, 2016)

Dalam Skenario 3, Terusan Kra dan Kawasan Ekonomi Khusus di Thailand Selatan akan hidup. Nantinya akan ada pelabuhan bongkar muatan yang ditempatkan di bagian tengah terusan, sehingga akan memudahkan aktivitas ekspor dan impor ke Thailand. Menurut skenario ini, semua jalur laut yang melalui Selat Malaka tetap beraktifitas seperti sedia kala.

Dalam pembangunannya, Terusan Kra menimbulkan kerugian atau keuntungan bagi negara-negara di Asia Tenggara. Negara-negara yang akan menerima keuntungan besar dari pembangunan terusan ini adalah Myanmar, Kamboja, dan Vietnam. Negara tersebut memiliki Southern Economic Corridor (SEC) yang mana dapat mengembangkan wilayah pantainya untuk meningkatkan industri dan wisata sepanjang pesisir timur Thailand (Sisovanna, 2012; Sulong, 2012). Vietnam akan mendulang keuntungan besar dari pengiriman jalur laut yang akan melewati pantai selatannya. Sehingga pembangunan Pelabuhan selatan Vietnam dapat berpotensi menyaingi Singapura dan dapat merubah jalur pengiriman laut secara signifikan (Jensen, 2009).

Menurut Menon, sebagai Special Economic Zones (Kawasan Ekonomi Khusus/SEZ) dapat memaksimalkan kedudukan ekonomi di suatu Kawasan terkonsentrasi dan menstabilkan ekonomi berkelanjutan. Terusan Kra dianggap dapat menjadi pusat lalu lintas bisnis yang memiliki infrastruktur lebih canggih untuk mendukung kegiatan bisnis pengiriman jalur laut (Menon, 2018; Monika, 2020) 
Negara-negara pesisir yang terkena dampak besar adalah Singapura dan Indonesia sebagai negara yang menduduki dan menguasai Selat Malaka secara langsung (Irewati, 2011). Singapura selama ini mendapatkan keuntungan dari kapal-kapal yang melewati Selat Malaka. Singapura memanfaatkan Selat Malaka sebagai tempat peristirahatan atau rest area yang menawarkan persandaran dan peristirahatan kapal di dermaga untuk beberapa saat sebelum akhirnya melanjutkan perjalanan kembali. Maka dari itu, secara ekonomi negara tersebut bergantung pada Selat Malaka dan terkena dampak lebih besar pada pembangunan Terusan Kra.

Sedangkan Indonesia merasakan dampak tersebut apabila Indonesia tidak mengambil sikap dan mempersiapkan diri dari sekarang. Indonesia memiliki posisi baik untuk penawaran-penawaran jalur laut karena factor geografis Indonesia dalam keberadaan Selat Malaka. Indonesia sampai saat ini masih memiliki peluang apabila Terusan Kra berhasil dibangun, yaitu dengan memanfaatkan kota Batam yang telah direncanakan menjadi pelabuhan transit terbesar untuk bersaing dengan Singapura. Selain itu, Pelabuhan Kuala Tanjung di Sumatera Utara juga dapat menjadi opsi untuk menjadi pelabuhan transit paling strategis bagi kapal yang menuju Indonesia tanpa harus singgah di Singapura. Sebelumnya, BJ Habibie juga telah menggagas adanya pembangunan Pelabuhan Malahayati di Aceh sebagai salah satu pelabuhan transit terbesar seperti Pelabuhan Kuala Tanjung dengan skala internasional (Jafar, 2009). Indonesia dalam menyikapi pembangunan Terusan Kra juga merasakan dampak baik lainnya yaitu dengan adanya externalities atau peningkatan aktivitas ekonomi akibat manfaat yang diterima secara tidak langsung. Dalam hal perekonomian berencana yang dibangun Indonesia, Terusan Kra sama sekali tidak mengganggu dan membawa dampak baik pada perencanaan perekonomian maritim Indonesia.

Namun lain halnya dengan IDE-JETRO yang memprediksikan bahwa Indonesia dapat merugi secara besar-besaran apabila pembangunan dan pemanfaatan tidak dikerjakan dari sekarang. Pada tahun 2030, Indonesia diprediksi akan menderita kerugian besar pada Pendapatan Domestik Bruto (Rohmah et al., 2018).

Pada skenario pertama, kerugian yang dialami Indonesia tidak banyak. Hal ini disebabkan karena jalur Malaka tetap dibuka meski Kanal Kra telah diresmikan. Skenario kedua adalah skenario menggambarkan potensi kerugian yang paling besar yang akan diperoleh Indonesia yaitu penurunan sebanyak $0.33 \%$. Hal ini disebabkan Jalur Malaka "ditutup". Program transhipment berpotensi hanya dapat dilakukan oleh Singapura dan Indonesia tidak mendapatkan transhipment langsung. Skenario tiga juga memberikan $0 \%$ kerugian (Chen \& Kumagai, 2016).

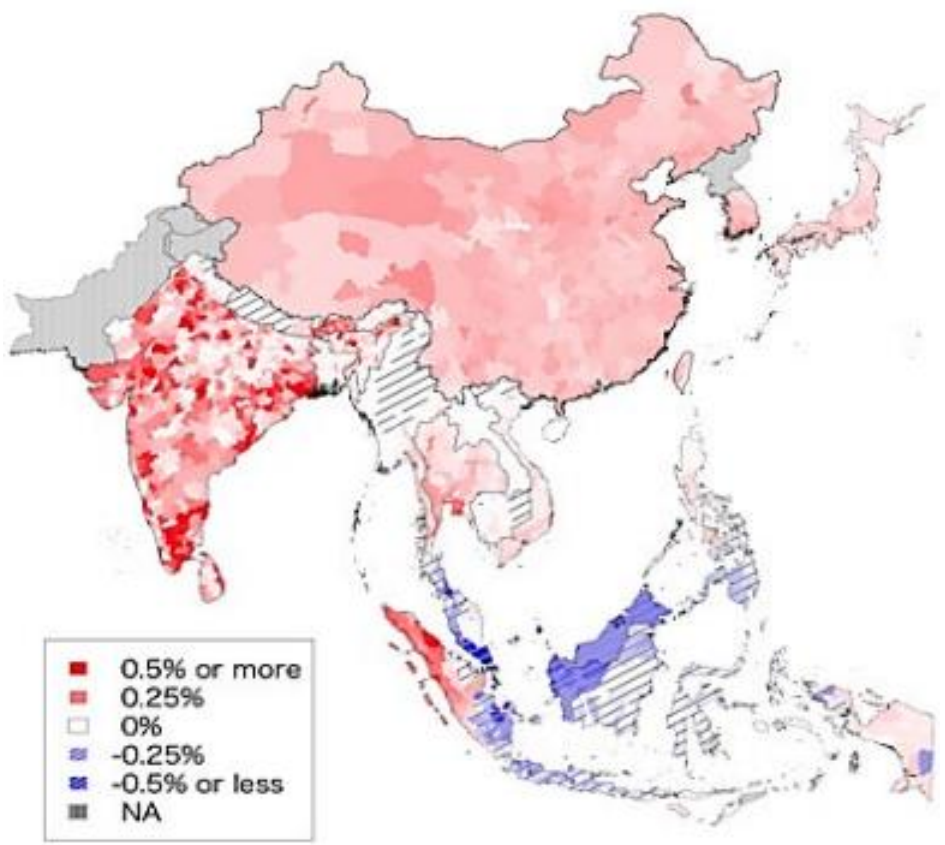

Gambar 4. Dampak Ekonomi dari Terusan Kra menurut Skenario 3 pada Tahun 2030 (Sumber: Chen \& Kumagai, 2016) 
Tabel 1. Dampak Ekonomi dari Terusan Kra dari Negara-negara di tahun 2030

\begin{tabular}{|c|c|c|c|c|c|c|}
\hline & \multicolumn{2}{|c|}{ Skenario 1} & \multicolumn{2}{|c|}{ Skenario 2} & \multicolumn{2}{|c|}{ Skenario 3} \\
\hline & $\begin{array}{c}\text { (juta } \\
\text { USD) }\end{array}$ & $\begin{array}{c}\text { (\% dari } \\
\text { Produk } \\
\text { Domestik } \\
\text { Bruto) }\end{array}$ & $\begin{array}{l}\text { (juta } \\
\text { USD) }\end{array}$ & $\begin{array}{c}\text { (\% dari } \\
\text { Produk } \\
\text { Domestik } \\
\text { Bruto) }\end{array}$ & $\begin{array}{l}\text { (juta } \\
\text { USD) }\end{array}$ & $\begin{array}{c}\text { (\% dari } \\
\text { Produk } \\
\text { Domestik } \\
\text { Bruto) }\end{array}$ \\
\hline Indonesia & -98 & $0.00 \%$ & $-11,660$ & $-0.33 \%$ & -83 & $0.00 \%$ \\
\hline Malaysia & -130 & $-0.01 \%$ & $-2,029$ & $-0.21 \%$ & -85 & $-0.01 \%$ \\
\hline Singapura & -371 & $-0.04 \%$ & $-7,027$ & $-0.83 \%$ & -353 & $-0.04 \%$ \\
\hline Thailand & 2,703 & $0.18 \%$ & 2,742 & $0.18 \%$ & 4,244 & $0.28 \%$ \\
\hline Philipina & 382 & $0.04 \%$ & 359 & $0.03 \%$ & 389 & $0.04 \%$ \\
\hline Brunei & -9 & $-0.04 \%$ & -111 & $-0.51 \%$ & -8 & $-0.04 \%$ \\
\hline Kamboja & 8 & $0.02 \%$ & 9 & $0.02 \%$ & 9 & $0.02 \%$ \\
\hline Laos & 2 & $0.01 \%$ & 2 & $0.01 \%$ & 2 & $0.01 \%$ \\
\hline Myanmar & 9 & $0.01 \%$ & 9 & $0.01 \%$ & 9 & $0.01 \%$ \\
\hline Vietnam & 484 & $0.09 \%$ & 486 & $0.09 \%$ & 491 & $0.09 \%$ \\
\hline ASEAN 10 & 2.980 & $0.03 \%$ & -17.221 & $-0.20 \%$ & 4.615 & $0.05 \%$ \\
\hline
\end{tabular}

Sumber: Institute of Developing Economies Japan External Trade Organization (IDE-JETRO)

Kebesaran Singapura selain dari keberhasilan pembangunan dalam segala aspek adalah berkat pemanfaatan posisi geopolitiknya yang begitu tertata dan terencana dengan sangat baik, yakni membangun dan menjalankan Pelabuhan termodern dan terbesar di kawasan Asia Tenggara. Taring kekuasaan atas kontrol Selat Malaka ditancapkan secara sistemik sejak Singapura lepas dari Malaysia pada 1963, sehingga Siapapun yang melewati Selat Malaka wajib untuk tidak transit di Pelabuhan Singapura. Dengan sistem yang sudah terbangun mapan ini, Singapura menjadi sosok check point dan penjaga gerbang masuk keluar bagi Kapal-kapal dagang yang melintasi selat tersibuk kedua di dunia. Hasilnya, Singapura mendapatkan geyser keuntungan yang fantastis bagi pundi pundi keuangannya, luar biasa. Small Country with a Big Power. Singapura sebagai salah satu negara yang terkena dampak besar juga mendapatkan dampak kerugian atas Terusan Kra. Singapura berhasil menyumbangkan $7 \%$ pendapatan industry maritim kepada perekonomian negara.

\section{KESIMPULAN}

Terusan Kra yang nantinya akan mengesampingkan Selat Malaka membawa dampak besar bagi perekonomian negara-negara yang menggantungkan perekonomian pada Selat Malaka. Negara-negara pesisir yang terkena dampak besar adalah Singapura dan Indonesia. Indonesia sampai saat ini masih memiliki peluang apabila Terusan Kra berhasil dibangun, yaitu dengan memanfaatkan kota Batam yang telah direncanakan menjadi pelabuhan transit terbesar untuk bersaing dengan Singapura. Sedangkan Singapura masih memiliki peluang pada skenario dua sebagai jalur pengumpan untuk Terusan Kra nantinya. Dengan berubahnya jalur pelayaran, maka peta perekonomian perairan di sekitar terusan Kra juga dapat terguncang dengan penurunan ekonomi sebesar $0,33 \%$.

\section{DAFTAR PUSTAKA}

Arno Maierbrugger, 2015, \$28Bn Kra Canal to Provide Shipping Shortcut, Gulf Times Newspaper Doha, May.

Billington, M., 2016, Kra Canal: One of the Greatest Achievements of Modern History, Executive Intelligent Review, 43(24):19-22

Chen, C. \& Kumagai, S., 2016, Economic Impacts of the Kra Canal: An Application of the Automatic Calculation of Sea Distances by a GIS, Institute of Developing Economies, Japan External Trade Organization (IDE-JETRO), 568:1-42 
Harahap, I., 2019, Dampak Pembangunan Terusan Kra di Thailand Terhadap Ekonomi Indonesia, Jurnal Wacana Politik, 4(1):68-80

Irewati, A., 2011, Dinamika Perbatasan Wilayah Laut di Selat Malaka - Singapura, Jurnal Penelitian Politik,8(2):183-194

Jafar, M., 2009, Perkembangan dan Prospek Partai Politik Lokal di Propinsi Nanggroe Aceh Darussalam, Penelitian Tesis Program Studi Magister IImu Politik, Universitas Diponegoro.

Jensen, A.C.M., 2009, Vietnam's Port Potential: the Economic and Political Implications of Vietnam's Port Renovation, Futuregram, 9(4):1-6.

Lau, C.Y. \& Lee, J.W.C., 2016. The Kra Isthmus Canal: A New Strategic Solution for China's Energy Consumption Scenario?. Environmental management, 57(1):1-20

Malaka, T., 2017. Terusan Kra Thailand Bakal Mengguncang Dunia Maritim Indonesia dan Singapura, Bangka Pos, Tribun News, Kamis, 30 November 2017.

Menon, R., 2018. Thailand's Kra Canal: China's Way Around the Malacca Strait, The Diplomat, 6.

Menteri Perencanaan Pembangunan Nasional/Kepala Badan Perencanaan Pembangunan Nasional, 2017. Arah Kebijakan Pembangunan Kemaritiman,

Monika, F., 2020. Indonesia's maritime strategy facing The Kra Isthmus Canal agenda. Jurnal Pendidikan Geografi: Kajian, Teori, dan Praktek dalam Bidang Pendidikan dan IImu Geografi, 25(1):39-53.

Peng Er, L. 2018. Thailand's Kra Canal Proposal and China's Maritime Silk Road: Between Fantasy and Reality?. Asian Affairs: An American Review, 45(1):1-17.

Rahmadani, S., Kusmanto, H. \& Warjio, W., 2019, Strategi Cina Menghadapi "Malacca Dilemma" dalam Rangka Pengamanan Jalur Energi Cina di Selat Malaka, Jurnal Pendidikan IImu-ilmu Sosial, 11(1):143.

Rahman, N.S.F.A., Salleh, N.H.M., Najib, A.F.A. and Lun, V.Y., 2016. A descriptive method for analysing the Kra Canal decision on maritime business patterns in Malaysia. Journal of Shipping and Trade, 1(1):1-16.

Rohmah, N., Parentio, R., Imron, R.C., \& Setyawan, A.B. 2019. Pengaruh rencana pembangunan terusan kra terhadap neraca ekspor impor asia tenggara. In Prosiding SNMEB (Seminar Nasional Manajemen dan Ekonomi Bisnis) 2018 Fakultas Ekonomi dan Bisnis Universitas Mulawarman.

Sisovanna, S., 2012. A Study on Cross-Border Trade Facilitation and Regional Development Along Economic Corridors in Cambodia, BRC Research Report No. 8

Su, S., 2015. Looking Ahead: The Port Industry - How ASEAN Ports Respond to the Changing Global Maritime Trade Trends?, BMT Asia Pacific, Des Voeux Road Central Hongkong.

Sulong, R.S. 2012. The Kra Canal and Southeast Asian Relation. Journal of Current Southeast Asian Affairs, 31(4):109-125

Tanapura, S., 1984. Thailand's Kra Canal Project Wins a Regional Mandate. Executive Intelligent Review, 11(45):4-7 